Mycologia, 106(1), 2014, pp. 119-132. DOI: 10.3852/13-073

(C) 2014 by The Mycological Society of America, Lawrence, KS 66044-8897

\title{
Multigene phylogenies of Ophiostomataceae associated with Monterey pine bark beetles in Spain reveal three new fungal species
}

Pedro Romón ${ }^{1}$

Department of Genetics, Forestry and Agricultural Biotechnology Institute (FABI), University of Pretoria, Pretoria 0002, South Africa

Z. Wilhelm de Beer

Department of Microbiology and Plant Pathology, Forestry and Agricultural Biotechnology Institute (FABI), University of Pretoria, Pretoria 0002, South Africa

XuDong Zhou CERC, China Eucalypt Research Center, Chinese Academy of Forestry, Zhanjiang 524022, GuangDong, China

Tuan A. Duong

Department of Genetics, Forestry and Agricultural Biotechnology Institute (FABI), University of Pretoria, Pretoria 0002, South Africa

Brenda D. Wingfield Department of Genetics, Forestry and Agricultural Biotechnology Institute (FABI), University of Pretoria, Pretoria 0002, South Africa

Michael J. Wingfield

Department of Microbiology and Plant Pathology, Forestry and Agricultural Biotechnology Institute (FABI), University of Pretoria, Pretoria 0002, South Africa

Abstract: Ophiostoma species, some of which cause sapstain in timber and/or are mild pathogens, are common fungal associates of bark beetles (Coleoptera: Scolytinae). Three new Ophiostomataceae from Spain are recognized in the present study based on comparisons of sequence data for three gene regions as well as morphological characteristics. The new taxa are described as Ophiostoma nebulare sp. nov., Ophiostoma euskadiense sp. nov. and Graphilbum crescericum sp. nov.

Key words: $\beta$-tubulin gene, calmodulin gene, morphology, rRNA internal transcribed spacers, sequencing

\section{INTRODUCTION}

Adaptation facilitating insect dispersal, such as erect ascomata and conidiomata bearing sticky spores, has arisen frequently in the evolution of fungi in the

Submitted 5 Mar 2013; accepted for publication 24 Jun 2013

${ }^{1}$ Corresponding author. E-mail: Pedro.Romon@fabi.up.ac.za
Ascomycota. This morphological convergence has resulted in a confused taxonomy for species collectively treated in the so-called ophiostomatoid fungi (Wingfield et al. 1993, Seifert et al. 2013). These fungi all have morphologically similar sexual states residing in two phylogenetically unrelated orders, the Microascales and Ophiostomatales. The majority of known ophiostomatoid species belong to the Ophiostomatales, and traditionally the sexual (teleomorph) and asexual (anamorph) states of these fungi were classified in different genera. Thus one species could have two or sometimes three names, each representing a different state. However, in 2011 the International Code of Nomenclature for Algae, Fungi and Plants (ICN) was emended and currently only allows one species name for each fungus, with the oldest genus name having priority (Hawksworth 2011, Hawksworth et al. 2011). The application of the new rules inevitably led to emended concepts for several of the ophiostomatoid genera, as well as name changes in the Ophiostomatales (de Beer and Wingfield 2013, de Beer et al. 2013). These changes have to be considered in all studies dealing with the biodiversity of these fungi.

Bark beetles that infest conifers carry many different ophiostomatoid fungi including those related to Ophiostoma (Jacobs and Kirisits 2003; Kim et al. 2003; Zhou et al. 2004, 2006; Kirisits 2007; Romon et al. 2007; Linnakoski et al. 2008, 2009; Masuya et al. 2009; Jankowiak and Kolarik 2010; Linnakoski et al. 2010; Paciura et al. 2010) and Ceratocystis (Harrington and Wingfield 1998, Harrington et al. 2002, van Wyk et al. 2004, Viiri and Lieutier 2004, Yamaoka et al. 2009, Reid et al. 2010). Although many of these fungi have the ability to cause lesions when inoculated into conifers (e.g. Grosmannia clavigera [Owen et al. 1987], Leptographium terebrantis [Parmeter et al. 1989], L. wingfieldii [Jankowiak 2006], Ophiostoma ips [Raffa and Smalley 1988], O. minus [Jankowiak 2006], Ceratocystis laricicola [Redfern et al. 1987] and C. polonica [Christiansen and Solheim 1990]), most are not considered pathogens in their own right (Six and Wingfield 2011). The only species able to cause disease independently of its beetle vectors is $L$. wageneri, the causal agent of black stain root disease (Morrison and Hunt 1988). Other species, such as $O$. ips, O. minus, O. piceae, $O$. piliferum and $O$. pluriannulatum, are best considered as agents of sapstain (Seifert 1993). 
Knowledge of bark beetle-associated fungi in the Iberian Peninsula is limited (de Ana Magán 1982, 1983; Fernández et al. 2004; Villarreal et al. 2005; Romón et al. 2007). Only two studies deal with the taxonomy of these fungi. One (de Ana Magán 1983) erroneously described a new species, Leptographium gallaeiciae, that later was identified as Ophiostoma serpens (Jacobs and Wingfield 2001). Another fungus in this group, Ophiostoma sejunctum (Villarreal et al. 2005), has been described, suggesting that fungi in the region deserve more study. Pinus radiata (Monterey pine) is the most economically important conifer species in Spain with exotic plantations covering an area of 270000 ha. Romón et al. (2007) studied the biodiversity and spatiotemporal ecological segregation of several ophiostomatalean fungi differentially associated with 14 insect species colonizing $P$. radiata in northern Spain. The present study considers the identity, nomenclature and phylogenetic relationships of three new species, collected by Romón et al. (2007), revealed by multigene sequencing and phylogenetics.

\section{MATERIALS AND METHODS}

Isolates. - All isolates used in this study were deposited both in the Culture Collection (CMW) of the Forestry and Agricultural Biotechnology Institute (FABI), University of Pretoria, Pretoria, South Africa, and in the Spanish Type Culture Collection (CECT), University of Valencia, Valencia, Spain. Isolates of the new taxa also were deposited in the Centraalbureau voor Schimmelcultures (CBS), Utrecht, the Netherlands, and their corresponding dried holo- and paratypes were deposited in the National Collection of Fungi of South Africa (PREM). The origin, number, collection and GenBank numbers of the isolates and sequences used in the phylogenetic analyses are presented (TABLE I).

DNA extraction, PCR amplification, DNA sequencing and phylogenetic analysis.-Two milliliter Eppendorf tubes containing $1 \mathrm{~mL}$ malt extract broth at $2 \%$ (wt/vol) were inoculated by transferring hyphal tips from the edges of individual colonies. After $15 \mathrm{~d}$ static incubation at $25 \mathrm{C}$, DNA was extracted using Prepman Ultra Sample Preparation Reagent (Applied Biosystems). PCR amplification was performed with primers ITS1-F (5'-CTTGGTCATTTAGAGGAAGTAA-3') and ITS4 (5'-TCCTCCGCTTATTGATATGC-3') (White et al. 1990) to amplify the ITS1-5.8SITS2 region of rDNA. The template DNA was amplified in a $50 \mu \mathrm{L}$ PCR reaction volume, consisting of $5 \mu \mathrm{L} 10 \times$ reaction buffer, $5 \mu \mathrm{L} \mathrm{MgCl} 2(25 \mathrm{mM}), 5 \mu \mathrm{L}$ dNTPs $(10 \mathrm{mM}), 1 \mu \mathrm{L}$ each primer $(10 \mu \mathrm{M}), 1.5 \mu \mathrm{L}$ DNA solution and $0.5 \mu \mathrm{L}$ Super-Therm Taq polymerase. PCR reactions were performed on a GeneAmp PCR System 9700 (Applied Biosystems) with an initial denaturation step of $2 \mathrm{~min}$ at $95 \mathrm{C}$, followed by 40 cycles of denaturation at $95 \mathrm{C}(30 \mathrm{~s})$, annealing at 52-55 C (30 s) and elongation at $72 \mathrm{C}$ (1 min). A final extension was conducted $8 \mathrm{~min}$ at $72 \mathrm{C}$.

In cases where ITS sequences were not sufficient to distinguish species, amplicons also were obtained for the $\beta$ tubulin gene with primers T10 (5'-ACGATAGGTTCACCTCCAGAGAC-3') or Bt2a (5'-GGTAACCAAATCGGTGCGCTTTC-3') with Bt2b (5'-GGTAACCAAATCGGTGCTGCTTTC-3') (Glass and Donaldson 1995) and part of the calmodulin gene with primers CL1 (5'-GARTWCAAGGAGGCCTTCTC-3') and CL2A (5'-TTTTGCATCATGAGTTGGAC-3') (O'Donnell 2000, Romeo et al. 2011). PCR conditions for calmodulin gene amplification were the same as those for ITS, whereas for $\beta$-tubulin the cycle included an initial denaturation step of 4 min at $95 \mathrm{C}$, followed by 35 cycles of denaturation for $1 \mathrm{~min}$ at $95 \mathrm{C}$, annealing $1 \mathrm{~min}$ at $47-52 \mathrm{C}$ and elongation $1 \mathrm{~min}$ at $72 \mathrm{C}$, with a final elongation step of $7 \mathrm{~min}$ at $72 \mathrm{C}$. PCR products were viewed under UV illumination on a $1 \%$ agarose gel stained with Gelred (Biotium), run in a Wide Mini-Sub Cell GT Electrophoresis System (BioRad) and digitalized in a white-ultraviolet transilluminator Gel Documentation System (UVP). Amplification products were purified with the High Pure PCR Product Purification Kit (Roche).

Sequencing was performed with ABI Prism Big Dye Terminator Cycle Sequencing Ready Reaction Kit on an ABI PRISM 377 autosequencer. Forward and reverse sequences were aligned and consensus sequences determined with ContigExpress, Vector NTI Advance 11.5.0 (Invitrogen). BLAST queries were conducted for preliminary identifications, after which datasets that included all the most up-to-date GenBank sequences were compiled in MEGA 5 (Tamura et al. 2011). Sequences were aligned online with MAFFT 6 (Katoh et al. 2002). Datasets were analysed with maximum likehood (ML), maximum parsimony (MP) and Bayesian inference (BI). ML analyses were performed with PhyML 3.0 (Guindon et al. 2006) after determining the substitution model in jModelTest 0.1.1 (Posada 2008). Support for nodes was estimated from 1000 bootstrap replicates. MP analyses were conducted with PAUP*: phylogenetic analysis using parsimony (*and other methods) 4.0b10 (Swofford 2003). Random stepwise addition heuristic searches were performed with tree-bisectionreconnection (TBR) branch-swapping active. Alignment gaps were treated as a fifth character state. Ten trees were saved per replicate and branches of zero length were collapsed. Confidence was estimated by performing 1000 bootstrap replicates (Felsenstein 1985) with fast-stepwise addition. BI analyses were carried out with MrBayes 3.1.2 (Ronquist and Huelsenbeck 2003). Markov chain Monte Carlo was run 5000000 generations with the best-fitting model selected by the Akaike information criterion in MrModeltest 2.3 (http://www.abc.se/ nylander). Trees were sampled every 100 generations. Burn-in values were determined with Tracer 1.4 (http://tree.bio.ed.ac.uk/software/tracer). All sampled trees lower than the burn-in values were discarded and a $50 \%$ majority rule consensus tree was constructed.

GenBank accession numbers of published sequences are revealed in the phylogenetic trees, while accession numbers of sequences obtained in the present study are presented TABLE I. Statistical values resulting from the respective 
Romón ET AL.: ThreE NEW OPHIOSTOMATACEAE SPECIES

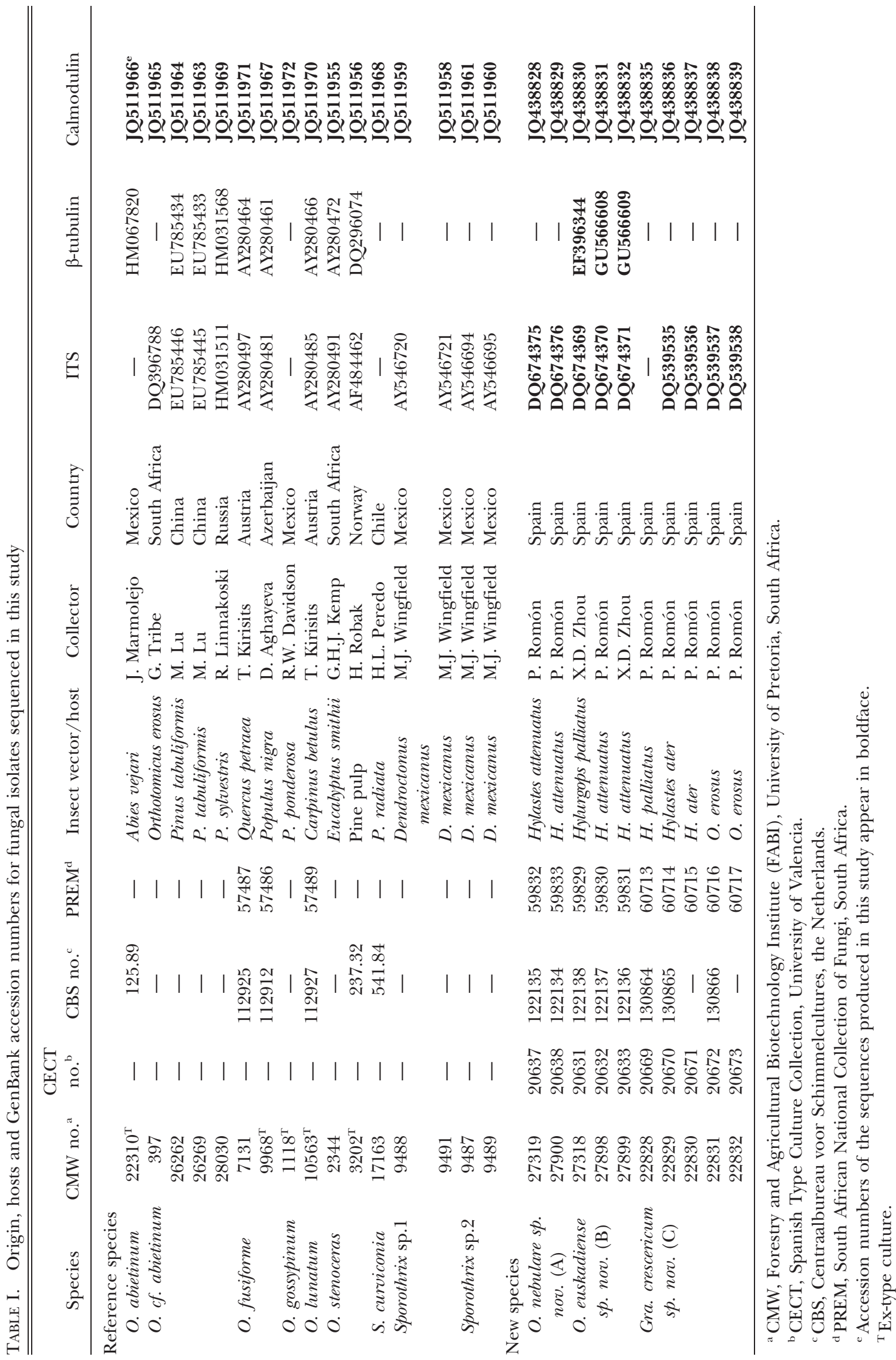




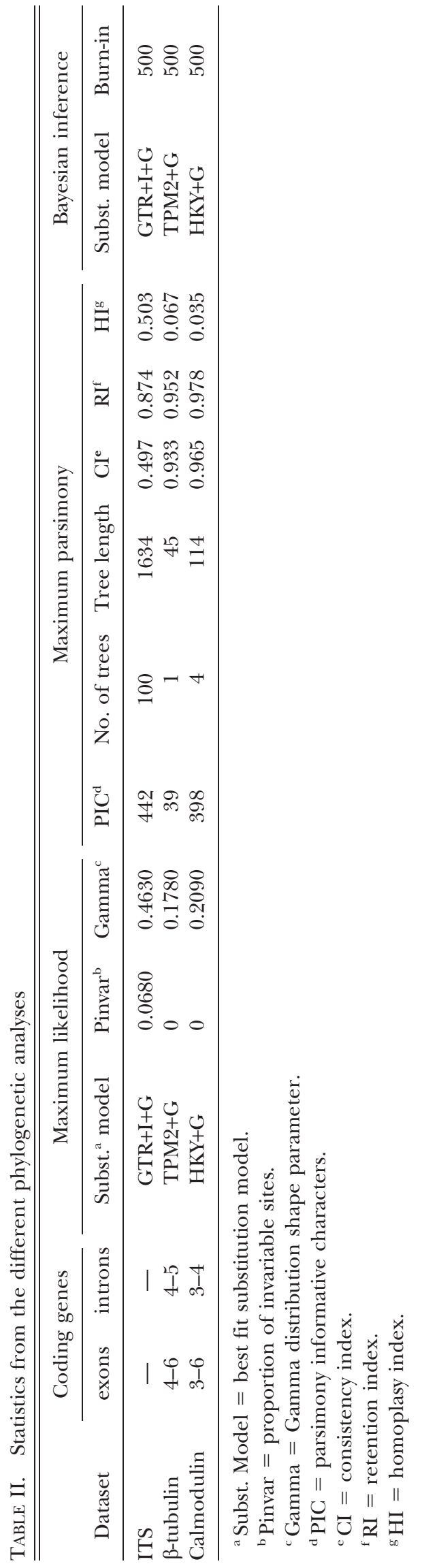

phylogenetic analyses are presented (TABLE II). DNA sequence matrices are available from TreeBase at http:// purl.org/phylo/treebase/phylows/study/TB2:S12569.

Culture characteristics and morphology.-Isolates representing the same species were grown and crossed in all possible combinations on $2 \%$ water agar and oatmeal agar with autoclaved pine twigs to induce production of perithecia (Grobbelaar et al. 2010). Perithecia and ascospores and/or slide cultures to observe anamorph structures were mounted in lactophenol on glass slides and examined with a Zeiss axioskop microscope. Fifty measurements were made for each taxonomically characteristic structure. All qualitatively and quantitatively informative characters, including those of mycelium, conidiophores, conidia, perithecia and ascospores, were characterized and compared with the most phylogenetically related species using relevant taxonomic keys and protologs. The measurements are presented as (minimum-) mean minus standard deviation - mean plus standard deviation (-maximum).

For each putative new taxon as well as closely related species, the optimal growth temperature for two isolates was determined by growing them at 5-35 $\mathrm{C}$ at $5 \mathrm{C}$ intervals in Sanyo MIR-253 incubators. A $5 \mathrm{~mm}$ diam agar disk was taken from the actively growing margin of a fresh colony of each isolate and inoculated onto the agar surface of six $2 \%$ MEA replicate plates for each temperature. Colony diameters were measured after $8 \mathrm{~d}$, and mean minimum, optimum and maximum growth temperatures were calculated. Mean growth was compared among isolates with ANOVA and Tukey test.

\section{RESUlts}

PCR, sequencing and phylogenetic analysis.-ITS15.8S-ITS2 sequences of the isolates obtained from bark beetles in Spain (Romon et al. 2007) confirmed the presence of 12 well defined and commonly occurring species (FIG. 1) and revealed three new taxa. The amplified ITS regions of isolates representing the taxa (A, B, C) were respectively 489, 532 and 537 bp long. ITS sequences of taxa A and $\mathrm{C}$ indicated that these two groups of isolates were different than all known species (FIG. 1) and respectively grouped in Ophiostoma sensu lato and Graphilbum. However, the ITS sequences of taxon B showed that it grouped near $O$. abietinum and related species in the Sporothrix schenckii-O. stenoceras complex but did not sufficiently distinguish among these species. For this reason $\beta$-tubulin and calmodulin sequences also were produced for these isolates, as well as for reference species for which sequences of these gene regions were not available (TABLE I). The $\beta$-tubulin amplicons of isolates of taxon B was 279 bp. Calmodulin gene sequences from isolates of the three species were respectively 612, 566 and 542 bp. For each of the sequence datasets, MP, ML and Bayesian analyses resulted in 


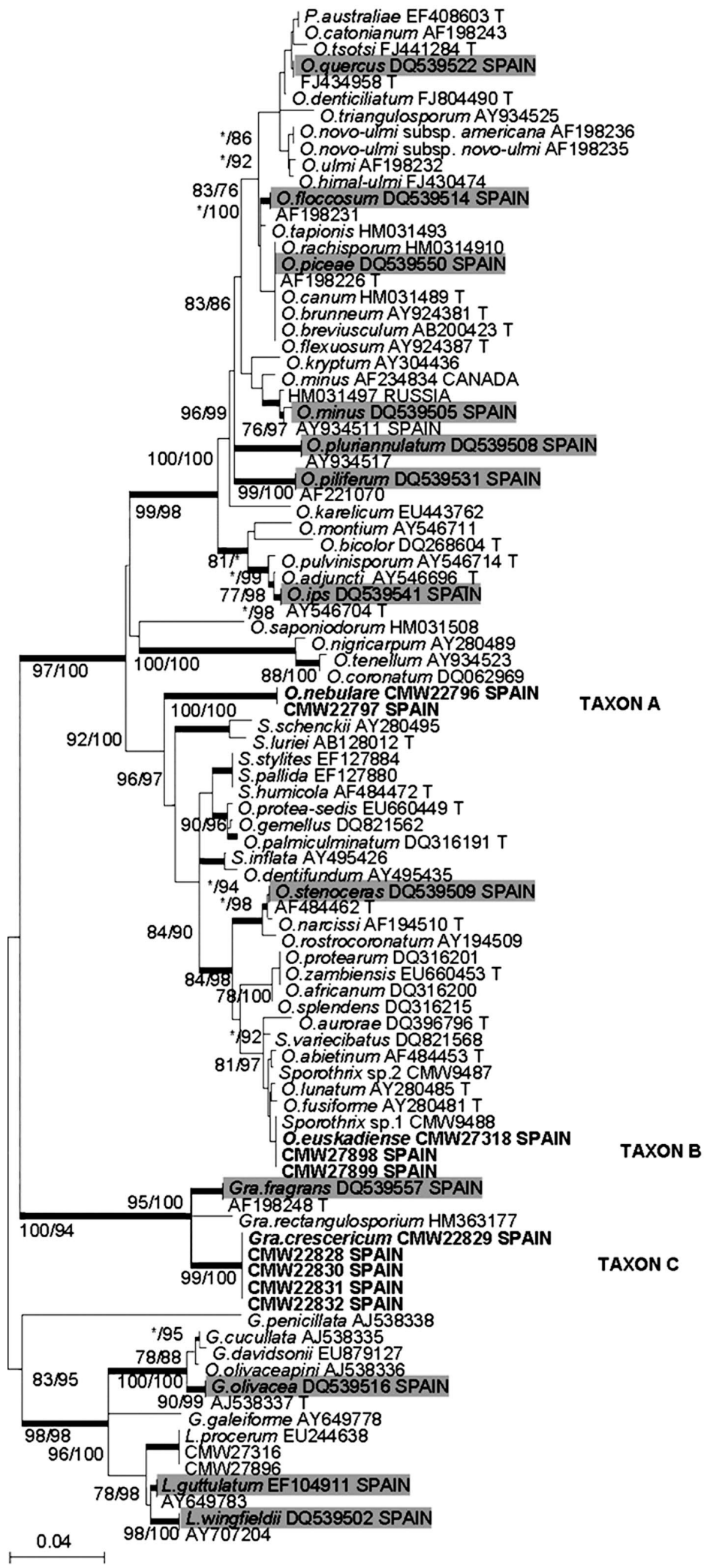

Ophiostoma

sensu

lato

FIG. 1. Phylogram based on ML analyses of ITS1-5.8S-ITS2 rDNA sequences, showing where fungal associates of pine bark beetles in Spain from the study of Romón et al. (2007) groups within the Ophiostomatales. Spanish isolates of known species are shaded, while those of novel taxa are printed in boldface. ML and MP bootstrap support values (1000 replicates) are indicated at the nodes. BI probabilities (above $90 \%$ ) are indicated by bold lines at the relevant branching points. $*=$ bootstrap values lower than $75 \% . \mathrm{T}=$ ex-type isolates. $\mathrm{Bar}=$ total nucleotide difference between taxa. $\mathrm{ML}=$ maximum likelihood. $\mathrm{MP}=$ maximum parsimony. $\mathrm{BI}=$ Bayesian inference. 

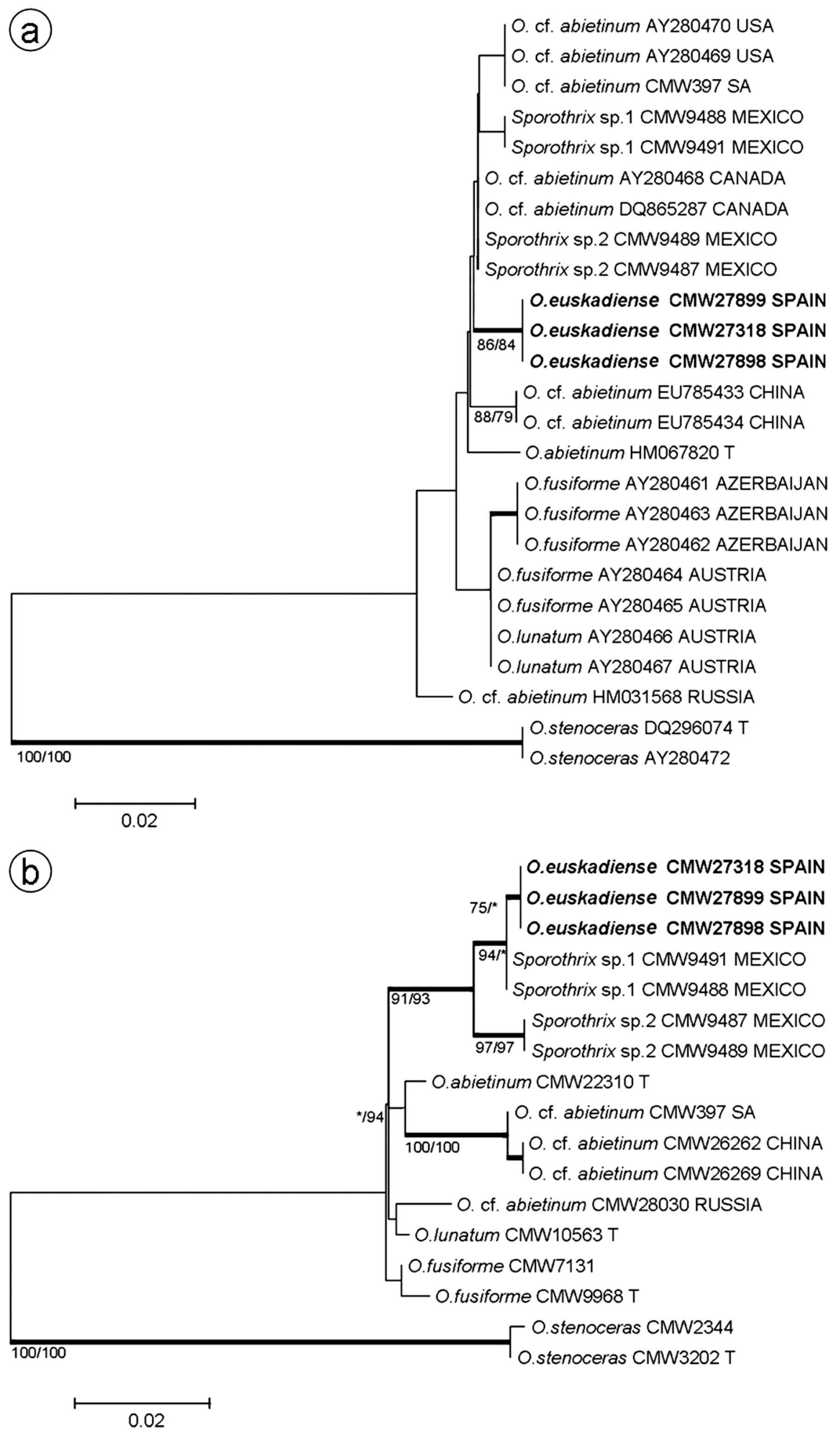

FIG. 2. a. Phylogram based on ML analyses of beta-tubulin (a) and calmodulin (b) gene sequences of the O. abietinum subcomplex. ML and MP bootstrap support values (1000 replicates) are indicated at the nodes. BI probabilities (above 90\%) are indicated by bold lines at the relevant branching points. $*=$ bootstrap values lower than $75 \%$. $\mathrm{T}=$ ex-type isolates. Bar $=$ total nucleotide difference between taxa. Boldface $=$ new species. $\mathrm{ML}=$ maximum likelihood. $\mathrm{MP}=$ maximum parsimony. $\mathrm{BI}$ $=$ Bayesian inference.

trees with similar topologies. Phylograms obtained with ML are presented for all the datasets (FIGS. 1, 2), with nodal support obtained from ML, MP and Bayesian inference indicated on the trees.
Culture characteristics and morphology.-Cultures representing the three new species were white, with little aerial mycelium, and morphologically similar in culture, except for taxon A that had a creamy color 


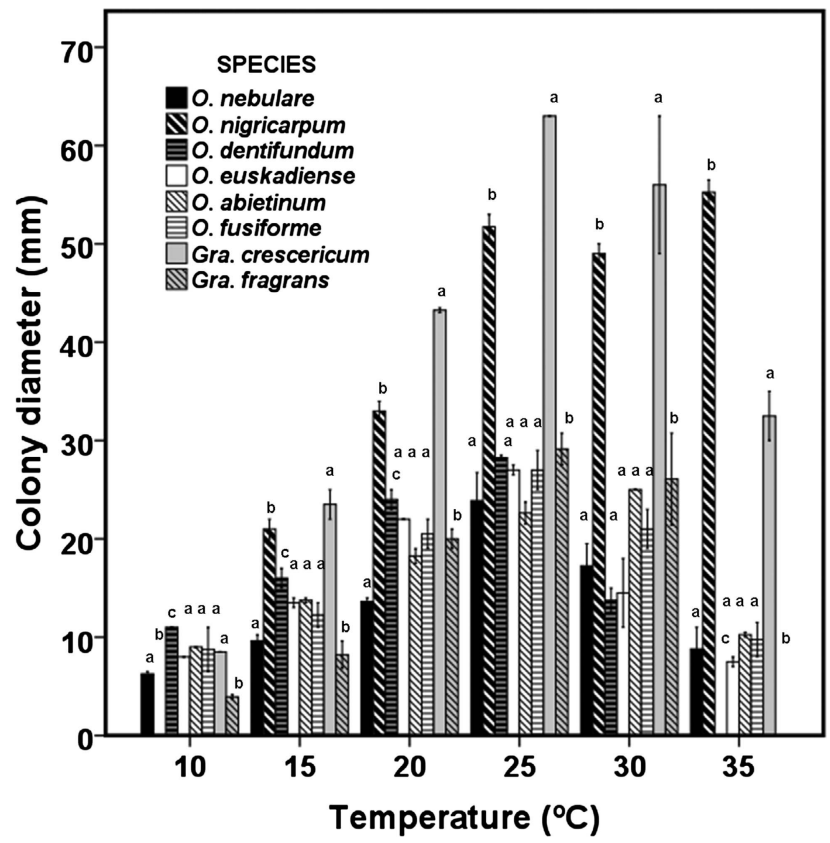

FIG. 3. Mean growth on MEA (two isolates per tested species, \pm standard deviation) of $O$. nebulare, O. euskadiense, Gra. crescericum and closely related species (groups respectively with black, dark gray and light gray bars) at a range of temperatures after $8 \mathrm{~d}$ in the dark. Means with different letter are significantly different within each species group and temperature $(P>0.05)$, by ANOVA followed by Tukey test.

on malt extract agar. Isolates representing taxon B produced abundant ascomata in culture. Growth comparisons showed that isolates representing taxon $\mathrm{C}$ grew faster than isolates in taxa $\mathrm{A}$ and $\mathrm{B}$ at all tested temperatures (FIG. 3), whereas taxon B isolates grew faster than taxon $\mathrm{A}$ at 10, 15 and $20 \mathrm{C}$. The optimum temperature for growth of isolates in taxa A, B and C was $25 \mathrm{C}$, with an average culture diameter of 24.2, 14.4 and $60.4 \mathrm{~mm}$ respectively in $8 \mathrm{~d}$ (FIG. 3).

\section{TAXONOMY}

Based on sequence comparisons and morphology, three groups of isolates from bark beetles colonizing $P$. radiata in Spain were found to represent undescribed species of Ophiostoma and Graphilbum in the order Ophiostomatales (TABLE III). These are described as follows:

\section{Taxon A:}

Ophiostoma nebulare P. Romón, Z.W. de Beer, M.J. Wingf., sp. nov.

FIG. 4

MycoBank MB564952

Perithecial bases dark, (83.44-)86.56-101.18 (-105.94) $\mu \mathrm{m}$ diam. Perithecial necks dark black, (169.50-)140.54-293.21(-365.86) $\mu \mathrm{m}$ long, (24.61-)
25.66-30.81(-30.93) $\mu \mathrm{m}$ wide at base, (8.56-)8.93$12.88(-13.94) \mu \mathrm{m}$ wide at the apex. Ostiolar hyphae present (8.20-)9.58-15.20(-16.21) $\mu \mathrm{m}$ long and (2.07-) 2.11-2.39(-2.47) $\mu \mathrm{m}$ wide. Ascospores allantoid, (3.00-) $3.12-4.23(-6.52) \times(1.28-) 1.42-1.79(-1.88) \mu \mathrm{m}$. Sporothrix-like anamorph: conidiophores (20.00-)20.2320.74(-20.87) $\mu \mathrm{m}$ long; conidia obovoid with truncate bases, (2.53-)2.91-3.70(-3.73) × (1.13-)1.14-1.35(-1.44) $\mu \mathrm{m}$. Colonies with optimal growth at $25 \mathrm{C}$ on $2 \%$ MEA, reaching $24.20 \mathrm{~mm}$ diam in $8 \mathrm{~d}$. Colonies whitish to cream with age, changing the media to dark creamy. Little aerial mycelia. Isolation frequency $1.2 \%$ from Hylastes attenuatus.

Etymology: Referring to the fact that this species causes malt extract agar to change from a dark honey to a darkcreamy color.

Holotype: SPAIN, Basque Country, Morga, Bizkaia, Hylastes attenuatus infesting Pinus radiata, Jul 2004, P. Romón (PREM 59832, ex-type culture CMW27319 = CECT20637 = CBS122135).

Additional specimens examined: SPAIN, Basque Country, Morga, Bizkaia, Hylastes attenuatus infesting Pinus radiata, Jul 2004, P. Romón (PREM 59833, ex-paratype culture CMW27900 $=$ CECT20638 $=$ CBS122134).

Taxon B:

Ophiostoma euskadiense P. Romón, Z.W. de Beer,

M.J. Wingf., sp. nov. MycoBank MB564953

FIG. 5

Perithecial bases dark, (54.19-)57.64-66.31(-69.69) $\mu \mathrm{m}$ diam. Perithecial necks (201.32-)204.15-213.28 (-219.12) $\mu \mathrm{m}$ long, (9.58-)10.18-12.91(-13.98) $\mu \mathrm{m}$ wide at base, (5.26-)5.62-8.83(-9.66) $\mu \mathrm{m}$ wide at the apex. Ostiolar hyphae present (36.67-)41.22-49.13 (-49.83) $\mu \mathrm{m}$ long and (3.07-)3.10-3.31(-3.37) $\mu \mathrm{m}$ wide. Ascospores allantoid, (3.15-)3.18-3.56(-3.56) $\times$ (1.90-)1.91-2.01(-2.00) $\mu \mathrm{m}$. Sporothrix-like anamorph: conidiophores (10.02-)10.22-10.76(-10.82) $\mu \mathrm{m}$ long; conidia clavate, (2.10-)2.21-2.95(-3.70) × (1.00-)1.21$1.81(-1.80) \mu \mathrm{m}$. Colonies with optimal growth at $25 \mathrm{C}$ on $2 \%$ MEA, reaching $14.36 \mathrm{~mm}$ diam in $8 \mathrm{~d}$. Colonies shiny white to yellowish in the center with age. Little aerial mycelia. Isolation frequency 0.2 and $0.4 \%$ respectively from Hylurgops palliatus and Hylastes attenuatus.

Etymology: Referring to the Basque Country (Euskadi) where this species first was collected.

Holotype: SPAIN, Basque Country, Morga, Bizkaia, Hylurgops palliatus infesting Pinus radiata, Jul 2004, X.D. Zhou (PREM 59829, ex-type culture CMW27318 = CECT20631 = CBS122138).

Additional specimens examined: SPAIN, Basque Country, Morga, Bizkaia, Hylastes attenuatus infesting Pinus radiata, Jul 2004, P. Romón (PREM 59830, ex-paratype culture CMW27898 = CECT20632 = CBS122137); SPAIN, Basque Country, Morga, Bizkaia, Hylastes attenuatus infesting Pinus 

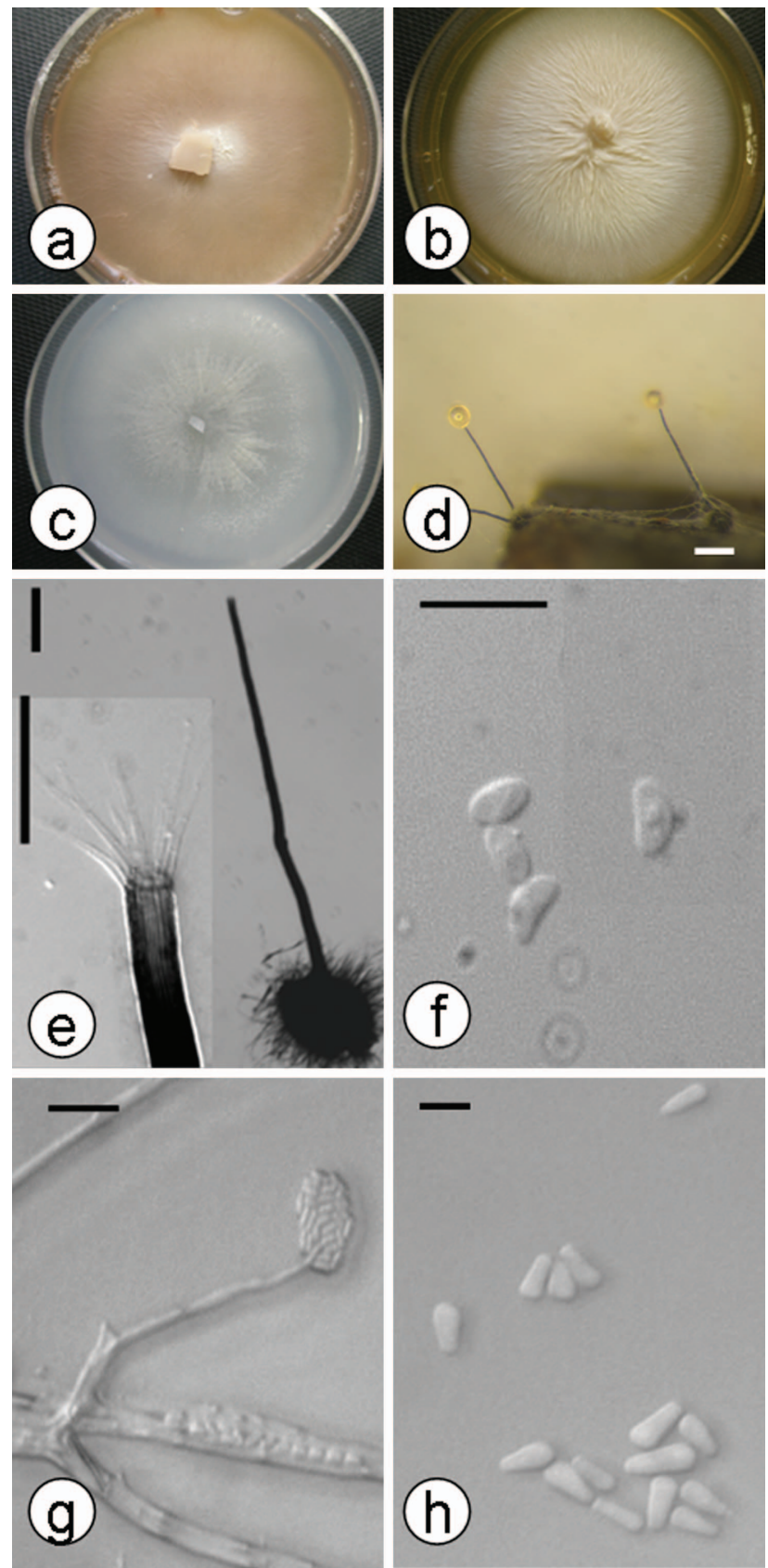

FIG. 4. Ophiostoma nebulare (CMW27319). a-d. Growing respectively on 2\% MEA, PDA, OA and WA-twigs (bar = $2000 \mu \mathrm{m})$. e. Perithecium (bar $=100 \mu \mathrm{m}$ ) with ostiolar hyphae $($ bar $=25 \mu \mathrm{m})$. f. Allantoid ascospores $($ bar $=5 \mu \mathrm{m})$. g. Sporothrix-like conidiophore $(\mathrm{bar}=10 \mu \mathrm{m})$. h. Obovoid conidia with truncate bases (bar $=5 \mu \mathrm{m}$ ).

radiata, Jul 2004, X.D. Zhou (PREM 59831, ex-paratype culture CMW27899 = CECT20633 = CBS122136).

\section{Taxon C:}

Graphilbum crescericum P. Romón, Z.W. de Beer, M.J. Wingf., sp. nov. FIG. 6
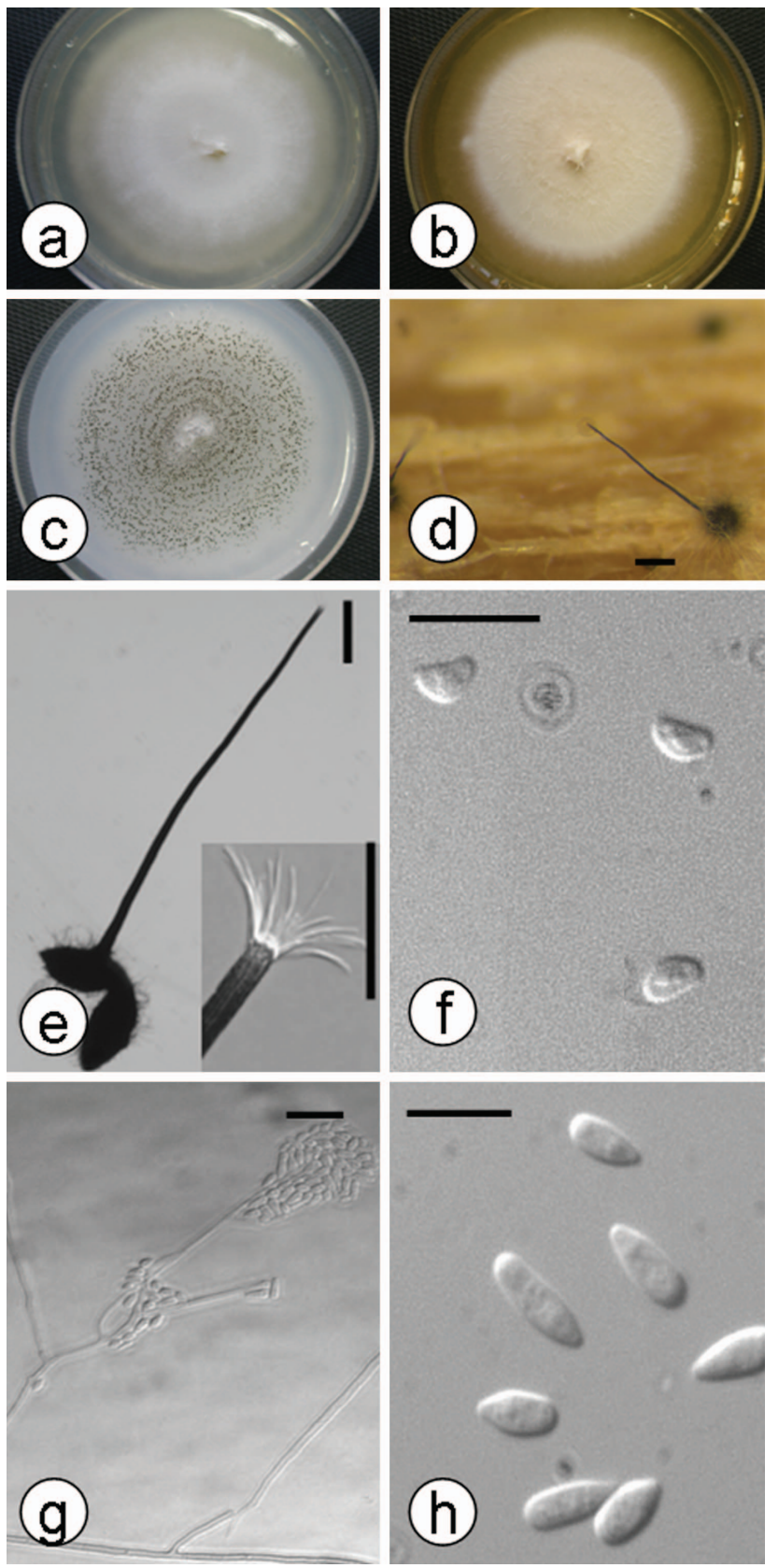

FIG. 5. Ophiostoma euskadiense (CMW27318). a-d. Growing respectively on 2\% MEA, PDA, OA and WA-twigs $($ bar $=2000 \mu \mathrm{m})$. e. Perithecium $($ bar $=100 \mu \mathrm{m})$ with ostiolar hyphae $($ bar $=25 \mu \mathrm{m})$. f. Allantoid ascospores (bar $=5 \mu \mathrm{m})$. g. Sporothrix-like conidiophore $(\mathrm{bar}=10 \mu \mathrm{m}) . \mathrm{h}$. Clavate conidia (bar $=5 \mu \mathrm{m})$.

Hyalorhinocladiella-like anamorph: conidiophores (16.32-)17.22-58.28(-69.92) $\mu \mathrm{m}$ long; conidia globose-subglobose, (4.39-) 4.52-5.73(-6.18) × (1.74-) 2.00-3.16(-3.34) $\mu \mathrm{m}$. Colonies with optimal growth at $25 \mathrm{C}$ on $2 \%$ MEA, reaching $60.44 \mathrm{~mm}$ diam in $8 \mathrm{~d}$. Colonies white. Isolation frequency $0.2,2$ and $1 \%$ respectively from Hylurgops palliatus, Hylastes ater and Orthotomicus erosus. 

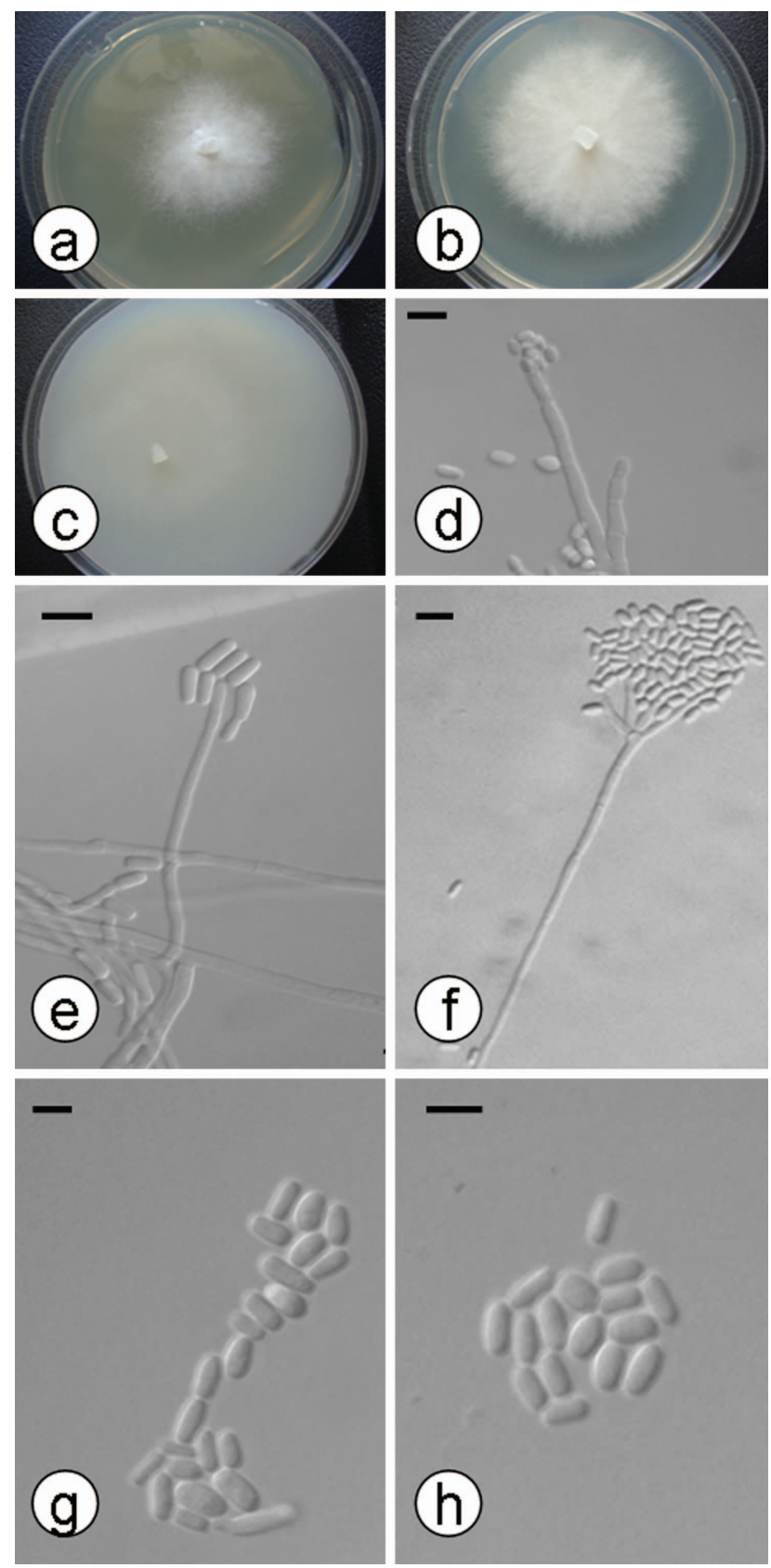

FIG. 6. Graphilbum crescericum (CMW22828). a-c. Growing respectively on 2\% MEA, PDA and OA. d-f. Hyalorhinocladiella-like conidiophores in different growing statuses (bars $=10 \mu \mathrm{m})$. g-h. Globose-subglobose conidia (bars = $5 \mu \mathrm{m})$.

Etymology: Referring to the rapid mycelial growth of this fungal species.

Holotype: SPAIN, Basque Country, Morga, Bizkaia, Hylurgops palliatus infesting Pinus radiata, Jul 2004, P. Romón (PREM 60713, ex-type culture CMW22828

= CECT20669 = CBS130864).

Additional specimens examined: SPAIN, Basque Country, Morga, Bizkaia, Hylastes ater infesting Pinus radiata, Jul
2004, P. Romón (PREM 60714, ex-paratype culture CMW22829 = CECT20670 = CBS130865); SPAIN, Basque Country, Morga, Bizkaia, Hylastes ater infesting Pinus radiata, Jul 2004, P. Romón (PREM 60715, ex-paratype culture CMW22830 = CECT20671); SPAIN, Basque Country, Morga, Bizkaia, Orthotomicus erosus infesting Pinus radiata, Jul 2004, P. Romón (PREM 60716, ex-paratype culture CMW22831 = CECT20672 = CBS130866); SPAIN, Basque Country, Morga, Bizkaia, Orthotomicus erosus infesting Pinus radiata, Jul 2004, P. Romón (PREM 60717, exparatype culture CMW22832 = CECT20673).

\section{DISCUSSION}

Romón et al. (2007) collected 1323 insects belonging to 14 species. Isolations yielded a total of 920 fungal cultures that included several mildly pathogenic species, such as L. wingfieldii (Jankowiak 2006), O. minus (Jankowiak 2006) and O. ips (Raffa and Smalley 1988), and well known species that cause sapstain, such as $O$. ips, O. minus, O. piceae and O. pluriannulatum (Seifert 1993). The molecular and morphological methodology used in the present study lets us describe two new fungal species residing in the $S$. schenckii-O. stenoceras complex in Ophiostoma sensu lato (O. nebulare, O. euskadiense) and a new species of Graphilbum (G. crescericum).

The S. schenckii-O. stenoceras complex is characterized by orange section-shaped allantoid ascospores without a sheath, a sporothrix-like anamorph and an absence of intron 4 and presence of intron 5 in the $\beta$ tubulin gene (de Beer et al. 2003, de Beer and Wingfield 2013, Zipfel et al. 2006). The complex includes several species associated with human sporotricosis (Marimon et al. 2006, 2007), soil (de Meyer et al. 2008), hardwoods (Aghayeva et al. 2004) or Protea infructescences (Roets et al. 2010). It is interesting that most species in the complex do not have specific bark beetle associates, while some species have been shown to be vectored by mites (Roets et al. 2008). The possibility that the newly described species also are vectored by mites phoretic on bark beetles should be studied further.

Among the isolates analyzed in the present study, $O$. nebulare formed a discrete, well supported clade that is peripheral to the major lineage of the $S$. schenckii-O. stenoceras complex (FIG. 1) and not distant from the $O$. nigricarpum complex. The ITS15.8S-ITS2 sequence of Ophiostoma nebulare, exclusively isolated from the root-feeding bark beetle Hylastes attenuatus, was homologous with that of $O$. nigricarpum (CMW650, AY280489; Aghayeva et al. 2004). The main morphological differences between $O$. nebulare and $O$. nigricarpum are growth at $10 \mathrm{C}$ and smaller colony diameters at 15-35 C, cream-colored mycelia in MEA medium with age, smaller Sporothrix conidia having a different shape, broader perithecium bases, 
longer perithecium necks and ostiolar hyphae and slightly longer ascospores. A $\beta$-tubulin sequence could not be obtained for this species.

Based on ITS sequences alone members of the $O$. euskadiense clade could not be distinguished from species in the $O$. abietinum subcomplex. ITS1-5.8SITS2 sequence differences were only two-point mutations of cytosine instead of thymine in positions 17 and 174 and two changes of thymine rather than cytosine in positions 173 and $530 \mathrm{bp}$. ITS sequence accounted for a total of zero and seven substitutions among $O$. euskadiense and Sporothrix sp.1 and Sporothrix sp.2 indicated by Zhou et al. (2004). Similarly $\beta$-tubulin sequences accounted for a total of five, four and three substitutions between $O$. euskadiense and O. abietinum, Sporothrix sp.1 and Sporothrix sp.2 respectively. Comparative growth did not reflect significant differences among all tested temperatures (FIG. 3). However calmodulin sequences (FIG. 2b) and morphology data (TABLE III) clearly separated these species within the $O$. abietinum subcomplex. Calmodulin sequence accounted for a total of 15, two and seven substitutions between $O$. euskadiense and O. abietinum, Sporothrix sp.1 and Sporothrix sp.2 respectively. The ITS1-5.8S-ITS2 sequence of Ophiostoma euskadiense, also mainly isolated from $H$. attenuatus, shared a high degree of homology with the type strain of Ophiostoma abietinum (CBS 125.89, AF484453; de Beer et al. 2003). The main morphological differences between these two species are shorter and clavate Sporothrixtype conidia, a narrower perithecium base, perithecia with shorter necks and slightly shorter ascospores. The beta-tubulin sequence included intron 5 but not intron 3 or intron 4 as characteristic of the complex.

Graphilbum crescericum did not have a sexual state and had the highest homology with Gra. rectangulosporium in what was formerly known as the Pesotum fragrans complex. De Beer et al. (2013) revealed that this complex represented a phylogenetically distinct lineage in the Ophiostomatales, for which they reinstated the older genus name, Graphilbum. They redefined the genus, previously considered an anamorph genus, based on the one fungus one name principles adopted in the ICN (Hawksworth 2011), to accommodate species known from either their sexual or asexual states or both. At present Graphilbum contains six known species, Gra. fragrans (Mathiesen-Käärik 1954, pesotum-type conidiophores), Gra. nigrum (Davidson 1958, slightly narrower conidia and sparse surface growth), Gra. sparsum (Davidson 1971, slightly smaller conidia and slow growth), Gra. curvicollis (Olchowecki and Reid 1974, slightly smaller clavate conidia and mycelium mostly immersed), Gra. microcarpum (Yamaoka et al. 2004, dark brown to black conidiophores), Gra. rectangulosporium (Ohtaka et al. 2006) and seven undescribed taxa, one of which is described here as Gra. crescericum. All these species have hyalorhinocladiella- to pesotum-like anamorphs, except Gra. rectangulosporium, for which no anamorph has been observed (Ohtaka et al. 2006).

Some ophiostomatoid species are mild pathogens and/or agents of bluestain. Nothing is known regarding the pathogenicity of the new Ophiostoma spp. described in the present study, whose pathogenic and saprophytic capabilities should be studied further. The discovery of a relatively large number of new taxa strongly reflects the fact that these fungi have been poorly studied in the introduced conifer stands of Spain. It is likely that similar studies on other conifers in Spain and/or southern Europe will yield additional new taxa in the Ophiostomatales. These not only will enhance our knowledge of this intriguing group of fungi but also the understanding of the fungal diversity associated with conifers in the region.

\section{ACKNOWLEDGMENTS}

We thank the National Research Foundation, members of the Tree Protection Co-operative Programme (TPCP), the Department of Education, Universities and Research of Basque Government, and the NRF/DST Center of Excellence in Tree Health Biotechnology (CTHB) for financial support. We also acknowledge the assistance of Dr Arturo Goldarazena in collecting specimens and Renate Zipfel for help with DNA sequencing.

\section{LITERATURE CITED}

Aghayeva DN, Wingfield MJ, De Beer ZW, Kirisits T. 2004. Two new Ophiostoma species with Sporothrix anamorphs from Austria and Azerbaijan. Mycologia 96:866-878, doi:10.2307/3762119

,-- Kirisits T, Wingfield BD. 2005. Ophiostoma dentifundum sp. nov. from oak in Europe, characterized using molecular phylogenetic data and morphology. Mycological Res 109:1127-1136, doi:10.1017/ S0953756205003710

Christiansen E, Solheim H. 1990. The bark beetle-associated blue-stain fungus Ophiostoma polonicum can kill various spruces and Douglas-fir. Eur J For Pathol 20:436-446, doi:10.1111/j.1439-0329.1990.tb01159.x

Davidson RW. 1958. Additional species of Ophiostomataceae from Colorado. Mycologia 50:661-670, doi:10.2307/3756174 1966. New species of Ceratocystis from conifers. Mycopathol Mycol Appl 28:273-286, doi:10.1007/ BF02051237 
1971. New species of Ceratocystis. Mycologia 63:515, doi:10.2307/3757679

de Ana Magán FJF. 1982. Las hogueras en el monte y el ataque del hongo Leptographium gallaeciae sp. nov. sobre P. pinaster Ait. Bol Serv Plagas 8:69-92.

- 1983. Enfermedad del Pinus pinaster en Galicia Leptographium gallaeciae F. Magan, sp. nov. An INIA/ Ser Forestal 7:165-169.

de Beer ZW, Harrington TC, Vismer HF, Wingfield BD, Wingfield MJ. 2003. Phylogeny of the Ophiostoma stenoceras-Sporothrix schenckii complex. Mycologia 95: 434-441, doi:10.2307/3761885

— Seifert KA, Wingfield MJ. 2013. A nomenclator for ophiostomatoid genera and species in the Ophiostomatales and Microascales. In: Seifert KA, de Beer ZW, Wingfield MJ, eds. The Ophiostomatoid fungi: expanding frontiers. CBS Biodiversity Series 12. Utrecht: the Netherlands. CBS Press. p 243-320.

—, Wingfield MJ. 2013. Emerging lineages in the Ophiostomatales. In: Seifert KA, de Beer ZW, Wingfield MJ, eds. The Ophiostomatoid fungi: expanding frontiers. CBS Biodiversity Series 12. Utrecht, the Netherlands: CBS Press. p 21-46.

de Meyer EM, de Beer ZW, Summerbell RC, Moharram AM, de Hoog GS, Vismer HF, Wingfield MJ. 2008. Taxonomy and phylogeny of new wood- and soil-inhabiting Sporothrix species in the Ophiostoma stenoceras-Sporothrix schenckii complex. Mycologia 100:647-661, doi:10.3852/07-157R

Felsenstein J. 1985. Confidence limits on phylogenetics: an approach using the bootstrap. Evolution 39:783-791, doi: $10.2307 / 2408678$

Fernández MMF, García AE, Lieutier F. 2004. Effects of various densities of Ophiostoma ips inoculations on Pinus sylvestris in northwestern Spain. For Pathol 34: 213-223, doi:10.1111/j.1439-0329.2004.00360.x

Glass NL, Donaldson GC. 1995. Development of primer sets designed for use with the PCR to amplify conserved genes from filamentous ascomycetes. Appl Environ Microbiol 61:1323-1330.

Grobbelaar J, de Beer ZW, Bloomer P, Wingfield M, Wingfield B. 2010. Ophiostoma tsotsi sp. nov., a wound-infesting fungus of hardwood trees in Africa. Mycopathologia 169:413-423, doi:10.1007/s11046-0099267-8

Guindon S, Dufayard JF, Lefort V, Anisimova M, Hordijk W, Gascuel O. 2006. New algorithms and methods to estimate maximum-likehood phylogenies: assessing the performance of PhyML 3.0. Syst Biol 59:307-321, doi:10.1093/sysbio/syq010

Harrington TC, Pashenova NV, McNew DL, Steimel J, Konstantinov MY. 2002. Species delimitation and host specialization of Ceratocystis laricicola and C. polonica to larch and spruce. Plant Dis 86:418-422, doi:10.1094/ PDIS.2002.86.4.418

—, Wingfield MJ. 1998. The Ceratocystis species on conifers. Can J Bot 76:1446-1457.

Hawksworth DL. 2011. A new dawn for the naming of fungi: impacts of decisions made in Melbourne in July 2011 on the future publication and regulation of fungal names. MycoKeys 1:7-20, doi:10.3897/mycokeys.1.2062

, Crous PW, Redhead SA, Reynolds DR, Samson RA, Seifert KA, Taylor JW, Wingfield MJ, Abaci Ö, Aime C, Asan A, Bai F-Y, de Beer ZW, Begerow D, Berikten D, Boekhout T, Buchanan PK, Burgess T, Buzina W, Cai L, Cannon PF, Crane JL, Damm U, Daniel H-M, van Diepeningen AD, Druzhinina I, Dyer PS, Eberhardt U, Fell JW, Frisvad JC, Geiser DM, Geml J, Glienke C, Gräfenhan T, Groenewald JZ, Groenewald M, de Gruyter J, Guého-Kellermann E, Guo L-D, Hibbett DS, Hong S-B, de Hoog GS, Houbraken J, Huhndorf SM, Hyde KD, Ismail A, Johnston PR, Kadaifciler DG, Kirk PM, Kõljalg U, Kurtzman CP, Lagneau PE, Lévesque CA, Liu X, Lombard L, Meyer W, Miller AN, Minter DW, Najafzadeh NJ, Norvell L, Ozerskaya SM, Öziç R, Pennycook SR, Peterson SW, Pettersson OV, Quaedvlieg W, Robert VA, Ruibal C, Schnürer J, Schroers HJ, Shivas R, Slippers B, Spierenburg H, Takashima M, Taşkın E, Thines M, Thrane U, Uztan AH, Van Raak M, Varga J, Vasco A, Verkley GJM, Videira SIR, de Vries RP, Weir BS, Yilmaz N, Yurkov A, Zhang N. 2011. The Amsterdam Declaration on Fungal Nomenclature. IMA Fungus 2:105-112, doi:10.5598/imafungus.2011.02.01.14

Jacobs K, Kirisits T. 2003. Ophiostoma kryptum sp. nov. from Larix decidua and Picea abies in Europe, similar to $O$. minus. Mycol Res 107:1231-1242, doi:10.1017/ S0953756203008402

Jankowiak R. 2006. Fungi associated with Tomicus piniperda in Poland and assessment of their virulence using Scots pine seedlings. Ann For Sci 63:801-808, doi:10.1051/ forest:2006063

— Kolařík M. 2010. Diversity and pathogenicity of ophiostomatoid fungi associated with Tetropium species colonizing Picea abies in Poland. Fol Microbiol 55:145154, doi:10.1007/s12223-010-0022-9

Katoh K, Misawa K, Kuma K, Miyata T. 2002. MAFFT: a novel method for rapid multiple sequence alignment based on fast Fourier transform. Nucleic Acid Res 30: 3059-3066, doi:10.1093/nar/gkf436

Kim JJ, Kim SH, Lee S, Breuil C. 2003. Distinguishing Ophiostoma ips and Ophiostoma montium, two bark beetle-associated sapstain fungi. FEMS Microbiol Let 222:187-192, doi:10.1016/S0378-1097(03)00304-5

Kirisits T. 2007. Fungal associates of European bark beetles with special emphasis on Ophiostomatoid fungi. In: Lieutier F, Day KR, Battisti A, Grégoire J-C, Evans HF, eds. Bark- and Wood-boring insects in living trees in Europe, a synthesis. Springer. p 181-236.

Linnakoski R, Beer ZW, Ahtiainen J, Sidorov E, Niemelä P, Pappinen A, Wingfield MJ. 2010. Ophiostoma spp. associated with pine- and spruce-infesting bark beetles in Finland and Russia. Persoonia 25:72-93, doi:10.3767/ $003158510 \times 550845$

— - , Roussi M, Niemelä P, Pappinen A, Wingfield MJ. 2008. Fungi, including Ophiostoma karelicum sp. nov., associated with Scolytus ratzeburgi infesting birch in Finland and Russia. Mycol Res 112:1475-1488, doi:10.1016/j.mycres.2008.06.007 
$\longrightarrow,-,-$, Solheim H, Wingfield MJ. 2009. Ophiostoma denticiliatum sp. nov. and other Ophiostoma species associated with the birch bark beetle in southern Norway. Persoonia 23:9-15, doi:10.3767/ 003158509X468038

Marimon R, Cano J, Gené J, Sutton DA, Kawasaki M, Guarro J. 2007. Sporothrix brasiliensis, S. globosa and $S$. mexicana, three new Sporothrix species of clinical interest. J Clin Microbiol 45:3198-3206, doi:10.1128/ JCM.00808-07

- Gené J, Cano J, Trilles L, Dos Santos Lazéra M, Guarro J. 2006. Molecular phylogeny of Sporothrix schenckii. J Clin Microbiol 44:3251-3256, doi:10.1128/ JCM.00081-06

Marmolejo JC, Butin H. 1990. New conifer-inhabiting species of Ophiostoma and Ceratocystis (Ascomycetes: Microascales) from Mexico. Sydowia 42:193-199.

Masuya H, Yamaoka Y, Kaneko S, Yamaura Y. 2009. Ophiostomatoid fungi isolated from Japanese red pine and their relationships with bark beetles. Mycoscience 50:212-223, doi:10.1007/S10267-008-0474-9

Mathiesen-Käärik A. 1954. Eine Übersicht über die gewöhnlichsten mit Borkenkäfern assoziierten Bläuepilze in Schweden und einige für Schweden neue Bläuepilze. Medd Stat Skogsforsk 43:1-74.

Morrison DJ, Hunt RS. 1988. Leptographium species associated with root disease of conifers in British Columbia. In: Harrington TC, Cobb FW, eds. Leptographium root diseases on conifers. St Paul, Minnesota: APS Press. p 81-96.

O'Donnell K. 2000. Molecular phylogeny of the Nectria haematococca-Fusarium solani species complex. Mycologia 92:919-938, doi:10.2307/3761588

Ohtaka N, Masuya H, Yamaoka Y, Kaneko S. 2006. Two new Ophiostoma species lacking conidial states isolated from bark beetles and bark beetles-infested Abies species in Japan. Can J Bot 84:282-293, doi:10.1139/b05-164

Olchowecki A, Reid J. 1974. Taxonomy of the genus Ceratocystis in Manitoba. Can J Bot 52:1675-1711, doi:10.1139/b74-222

Owen DR, Lindahl KQ Jr, Wood DL, Parmeter JR Jr. 1987. Pathogenicity of fungi isolated from Dendroctonus valens, $D$. brevicomis and $D$. ponderosae to ponderosa pine seedlings. Phytopathology 77:631-636, doi:10.1094/ Phyto-77-631

Paciura D, Zhou XD, de Beer ZW, Jacobs K, Ye H, Wingfield MJ. 2010. Characterisation of synnematous bark beetleassociated fungi from China, including Graphium carbonarium sp. nov. Fungal Divers 40:75-88, doi:10.1007/s13225-009-0004-x

Parmeter JR Jr, Slaughter GW, Chen MM, Wood DL, Stubbs HA. 1989. Single and mixed inoculations of ponderosa pine with fungal associates of Dendroctonus spp. Phytopathology 79:786-792, doi:10.1094/Phyto-79-768

Posada D. 2008. jModelTest: phylogenetic model averaging. Mol Biol Evol 25:1253-1256, doi:10.1093/molbev/ msn083

Raffa KF, Smalley EB. 1988. Response of red and jack pines to inoculations with microbial associates of the pine engraver, Ips pini (Coleoptera: Scolytidae). Can J For Res 18:581-586, doi:10.1139/x88-084

Redfern DB, Stoakley JT, Steele H, Minter DW. 1987. Dieback and death of larch caused by Ceratocystis laricicola sp. nov. following attack by Ips cembrae. Plant Pathol 36:467480, doi:10.1111/j.1365-3059.1987.tb02264.x

Reid J, Iranpour M, Rudski SM, Loewen PC, Hausner G. 2010. A new conifer-inhabiting species of Ceratocystis from Norway. Botany 88:971-983, doi:10.1139/B10-069

Roets F, de Beer ZW, Wingfield MJ, Crous PW, Dreyer LL. 2008. Ophiostoma gemellus and Sporothrix variecibatus from mites infesting Protea infructescences in South Africa. Mycologia 100:496-510, doi:10.3852/07-181R

— Wingfield BD, de Beer ZW, Wingfield MJ, Dreyer LL. 2010. Two new Ophiostoma species from Protea caffra in Zambia. Persoonia 24:18-28, doi:10.3767/ 003158510X490392

Romeo O, Scordino F, Criseo G. 2011. New insight into molecular phylogeny and epidemiology of Sporothrix schenckii species complex based on calmodulin-encoding gene analysis of Italian isolates. Mycopathologia 172:179-186, doi:10.1007/s11046-011-9420-z

Romón P, Zhou XD, Iturrondobeitia JC, Wingfield MJ, Goldarazena A. 2007. Ophiostoma species (Ascomycetes: Ophiostomatales) associated with bark beetles (Coleoptera: Scolytinae) colonizing Pinus radiata in northern Spain. Can J Microbiol 53:756-767, doi:10.1139/W07-001

Ronquist F, Huelsenbeck JP. 2003. MrBayes3: Bayesian phylogenetic inference under mixed models. Bioinformatics 19:1572-1574, doi:10.1093/bioinformatics/ btg 180

Seifert KA. 1993. Sapstain of commercial lumber by species of Ophiostoma and Ceratocystis. In: Wingfield MJ, Seifert KA, Webber JF, eds. Ceratocystis and Ophiostoma: taxonomy, ecology and pathogenicity. St Paul, Minnesota: APS Press. p 141-151.

— toid fungi: expanding frontiers. CBS Biodiversity Series 12. Utrecht, the Netherlands: CBS Press. 320 p.

Six DL, Wingfield MJ. 2011. The role of phytopathogenicity in bark beetle-fungus symbioses: a challenge to the classic paradigm. Ann Rev Entomol 56:255-272, doi:10.1146/annurev-ento-120709-144839

Swofford DL. 2003. PAUP* 4.0b10: phylogenetic analysis using parsimony (*and other methods). Sunderland, Massachusetts: Sinauer Associates.

Tamura K, Peterson D, Peterson N, Stecher G, Nei M, Kumar S. 2011. MEGA 5: molecular evolutionary genetics analysis using máximum-likelihood, evolutionary-distance and máximum-parsimony methods. Mol Biol Evol 28:2731-2739, doi:10.1093/molbev/msr121

van Wyk M, Roux J, Barnes I, Wingfield BD, Chhetri DB, Kirisits T, Wingfield MJ. 2004. Ceratocystis bhutanensis sp. nov., associated with the bark beetle Ips schmutzenhoferi on Picea spinulosa in Bhutan. Stud Mycol 50:365379 .

Viiri H, Lieutier F. 2004. Ophiostomatoid fungi associated with the spruce bark beetle, Ips typographus, in three areas in France. Ann For Sci 61:215-219, doi:10.1051/ forest:2004013 
Villarreal M, Rubio V, de Troya MT, Arenal F. 2005. A new Ophiostoma species isolated from Pinus pinaster in the Iberian Peninsula. Mycotaxon 92:259-268.

White TJ, Bruns T, Lee S, Taylor J. 1990. Amplification and direct sequencing of fungal ribosomal RNA genes for phylogenetics. In: Innis MA, Gelfand DH, Sninsky JJ, White TJ, eds. PCR protocols: a guide to methods and application. New York: Academic Press. p 315-322.

Wingfield MJ, Seifert KA, Webber JF. 1993. Ceratocystis and Ophiostoma: taxonomy, ecology and pathogenicity. St Paul, Minnesota: APS Press. 293 p.

Yamaoka Y, Chung W-H, Masuya H, Hizai M. 2009. Constant association of ophiostomatoid fungi with the bark beetle Ips subelongatus invading Japanese larch logs. Mycoscience 50:165-172, doi:10.1007/S10267-008-0468-7

, Masuya H, Ohtaka N, Kaneko S, Abe J-iP. 2004. Three new Ophiostoma species with Pesotum anamorphs associated with bark beetles infesting Abies species in Nikko, Japan. Mycoscience 45:277-286, doi:10.1007/ S10267-004-0179-7

Zhou XD, de Beer ZW, Cibrian D, Wingfield B, Wingfield MJ. 2004. Characterisation of Ophiostoma species associated with pine bark beetles from Mexico, including O. pulvinisporum sp. nov. Mycol Res 108: 690-698, doi:10.1017/S0953756204009918

_—_ ——, Wingfield MJ. 2006. DNA sequence comparisons of Ophiostoma spp., including Ophiostoma aurorae sp. nov., associated with pine bark beetles in South Africa. Stud Mycol 55:269-277, doi:10.3114/ sim.55.1.269

Zipfel RD, de Beer ZW, Jacobs K, Wingfield B, Wingfield MJ. 2006. Multigene phylogenies define Ceratocystiopsis and Grosmannia distinct from Ophiostoma. Stud Mycol 55: 77-99, doi:10.3114/sim.55.1.75 